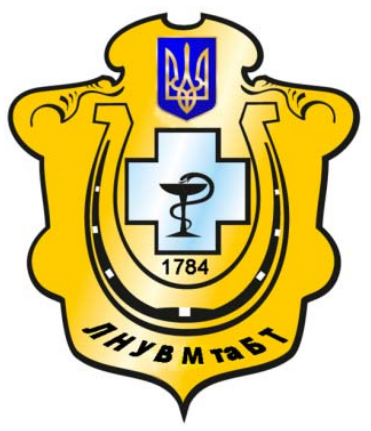

Науковий вісник Львівського національного університету ветеринарної медицини та біотехнологій імені С.3. Гжицького

Scientific Messenger of Lviv National University of Veterinary Medicine and Biotechnologies named after S.Z. Gzhytskyj

doi:10.15421/nvlvet6612

ISSN 2413-5550 print

ISSN 2518-1327 online

$\underline{\text { http://nvlvet.com.ua/ }}$

УДК 619:636.2:615.9:577.15:546.48

\title{
Influence of «Metisevit» on the activity of enzyme and nonenzyme link of antioxidant protection under the bull's body cadmium loading
}

\author{
B. Gutyj, Y. Lavryshyn, V. Binkevych, O. Binkevych, O. Paladischuk, J. Strons'kyj, I. Hariv \\ bvh@ukr.net

\begin{abstract}
Lviv National University of Veterinary Medicine and Biotechnologies named after S.Z. Gzhytskyi, Pekarska Str., 50, Lviv, 79010, Ukraine
\end{abstract}

\begin{abstract}
The article contains the research results of the effect of cadmium chloride on the indexes of enzyme and nonenzyme systems of antioxidant defense system in young cattle, such as the activity of catalase, superoxide dismutase, glutathione peroxidase, glutathione levels of vitamins $A$ and E. It is established that feeding calves at a dose of toxicant $0.04 \mathrm{mg} / \mathrm{kg}$ activity of catalase, superoxide dismutase, glutathione peroxidase, glutathione levels of vitamins A and $E$ in the blood of experimental animals decreased throughout the experiment. The lowest indicators of antioxidant in the blood of young cattle is set on the twenty -fourth day of the experiment, which is associated with increased activation of lipid peroxidation and the balance between antioxidant system and lipid peroxidation intensity. Given the cadmium load of young cattle it is used a new integrated drug with antioxidant action «Metisevit», which includes metifen, sodium selenite and vitamin E wich is founded as stimulating effects on the activity of antioxidant protection. In particular, it is established probable increase in activity of catalase, superoxide dismutase, glutathione peroxidase, glutathione levels, vitamin $A$ and vitamin $E$ in the blood of young cattle, which has performed cadmium stress. These changes occur through comprehensive action components of the drug «Metisevit» that leads to the normalization of metabolic processes and free radical in the body of the bull. The results of the research indicate antioxidant drug «Metisevit» in the application of its young cattle and the validity of his administration to improve the body's antioxidant status of chronic cadmium toxicosis.

Key words: pharmacology, toxicology, bull, antioxidant system, the drug «Metisevit» reduced glutathione, vitamin E, vitamin A, catalase, superoxide dismutase, glutathione peroxidase.
\end{abstract}

\section{Вплив препарату «Метісевіт» на активність ензимної та неензимної ланки антиоксидантного захисту організму бугайців за умов кадмісвого навантаження}

\author{
Б.В. Гутий, Ю.Ю. Лавришин, В.Я. Бінкевич, О.М. Бінкевич, О.Р. Паладійчук, Ю.С. Стронський, І.І. Харів \\ bvh@ukr.net
}

\begin{abstract}
Львівський національний університет ветеринарної медицини та біотехнологій імені С.3. Гжицького, вул. Пекарська, 50, м. Львів, 79010, Украӥна
\end{abstract}

\begin{abstract}
У статті наведено результати досліджень впливу хлориду кадмію на показники ензимної та неензимної системи антиоксидантного захисту у молодняку великої рогатої худоби, а саме на активність каталази, супероксиддисмутази, глутатіонпероксидази, рівень відновленого глутатіону, вітамінів А і Е. Встановлено, щзо згодовування бугайцям даного токсиканту у дозі 0,04 мг/кг маси тіла активність каталази, супероксиддисмутази, глутатіонпероксидази, рівень відновленого глутатіону, вітамінів А і Е у крові дослідних тварин упродовж усього досліду знижувався. Найнижчий рівень показників системи антиоксидантного захисту у крові молодняку великої рогатої худоби встановлено на двадиять четверту добу досліду, щьо пов 'язано із посиленою активачією процесів ліпопероксидації та порушенням рівноваги між активністю антиоксидантної системи та інтенсивністю перекисного окиснення ліпідів. За умов кадмісвого навантаження, молодняку вели-
\end{abstract}

Citation:

Gutyj, B., Lavryshyn, Y., Binkevych, V., Binkevych, O., Paladischuk, O., Strons'kyj, J., Hariv, I. (2016). Influence of «Metisevit» on the activity of enzyme and nonenzyme link of antioxidant protection under the bull's body cadmium loading. Scientific Messenger LNUVMBT named after S.Z. Gzhytskyj, 18, 2(66), 52-58. 
кої рогатої худоби застосовували новий комплексний препарат з антиоксидантною дією «Метісевіт», до складу якого входять метіфен, селеніт натрію та вітамін Е. Виявлено стимулювальний вплив препарату на активність системи антиоксидантного захисту. Зокрема, встановлено вірогідне підвищення активності каталази, супероксиддисмутази, глутатіонпероксидази, рівня відновленого глутатіону, вітаміну А та вітаміну Е в крові молодняку великої рогатої худоби, яким здійснювали кадмієве навантаження. Вказані зміни відбуваються завдяки комплексній дї складників препарату «Метісевіт», щуо призводить до нормалізації метаболічних та вільно радикальних процесів в організмі бугайців. Одержані результати досліджень вказують про антиоксидантну дію препарату «Метісевіт» при застосуванні його молодняку великої рогатої худоби та про обтрунтованість його введення з метою підвищення антиоксидантного статусу організму при хронічному кадмієвому токсикозі.

Ключові слова: фармакологія, токсикологія, бугайці, антиоксидантна система, препарат «Метісевіт», відновлений глутатіон, вітамін Е, вітамін А, каталаза, супероксиддисмутаза, глутатіонпероксидаза.

\title{
Влияние препарата «Метисевит» на активность ферментного и нефермен- тного звена антиоксидантной защиты организма бычков в условиях кад- миевой нагрузки
}

\author{
Б.В. Гутый, Ю.Ю. Лавришин, В.Я. Бинкевич, Е.М. Бинкевич, А.Р. Паладийчук, Ю.С. Стронский, И.И. Харив \\ bvh@ukr.net
}

\author{
Львовский национальный университет ветеринарной медицины и биотехнологий имени С.3. Гжицкого, \\ ул. Пекарская, 50, г. Львов, 79010, Украина
}

\begin{abstract}
В статье приведень результаты исследований влияния хлорида кадмия на показатели ферментной и неферментной системы антиоксидантной защиты у молодняка крупного рогатого скота, а именно на активность каталазы, супероксиддисмутазы, глутатионпероксидазы, уровень восстановленного глутатиона, витаминов А и Е. Установлено, что скармливание бычкам данного токсиканта в дозе 0,04 мг/кг массы тела активность каталазы, супероксиддисмутазы, глутатионпероксидазы, уровень восстановленного глутатиона, витаминов А и Е в крови подопытных животных в течение всего опыта снижался. Самый низкий уровень показателей системы антиоксидантной зашиты в крови молодняка крупного рогатого скота установлено на двадиать четвертые сутки опьта, что связано с усиленной активацией процессов липопероксидации и нарушением равновесия между активностью антиоксидантной системь и интенсивности перекисного окисления липидов. В условиях кадмиевого нагрузки, молодняка крупного рогатого скота применяли новый комплекснылй препарат с антиоксидантным действием «Метисевит», в состав которого входят метифен, селенит натрия и витамин Е. Выявлено стимулирующее влияние препарата на активность системь антиоксидантной защитьл. В частности, установлено достоверное повышение активности каталазы, супероксиддисмутазы, глутатионпероксидазы, уровня восстановленного глутатиона, витамина А и витамина Е в крови молодняка крупного рогатого скота, которым осуществляли кадмиевую нагрузку. Указанные изменения происходят благодаря комплексному действию составляюших препарата «Метисевит», что приводит к нормализации метаболических и свободно радикальных процессов в организме бычков. Полученные результаты исследований указывают о антиоксидантном действии препарата «Метисевит» при применении его молодняку крупного рогатого скота и обоснованности его введения с иелью повышения антиоксидантного статуса организма при хроническом кадмиевом токсикозе.
\end{abstract}

Ключевые слова: фармакология, токсикология, бычки, антиоксидантная система, препарат «Метисевит», восстановленный глутатион, витамин Е, витамин А, каталаза, супероксиддисмутаза, глутатионпероксидаза.

\section{Introduction}

Due to the intensive development of science and technology progress over the past decades the number of chemical compounds to which human and animal contact has increased significantly. Especially dangerous is pollution with heavy metals, at a high biological activity, particularly cadmium and its salts (Honskyy et al., 2001; Melnychuk et al., 2004; Gutyj, 2012).

Oxide and reduction reactions occupy an important role in the metabolic changes and their violation play an important and sometimes decisive role in the development of pathological processes. The processes of oxidation in the liver have very important role, where their participation is carried performing its basic body functions, including disposal of endo- and exotoxins. Toxic liver cadmium damages are accompanied by significant flow disturbances oxidative reactions that are characterized by some researches as «oxidative stress» (Honskyy et al., 2001; Gutyj, 2013).
Having established that during cadmium toxicity occurs enhance lipid peroxidation (Gutyj, 2013; Gutyj, 2015), we concluded that the action of cadmium to suppress excessive free radical reactions in animals, it is necessary to use drugs with a strong antioxidant effect that can inhibit processes of peroxidate oxidation of lipids. With a large number of antioxidants in cadmium toxicosis bull, we studied the «Metisevit» prophylactic effect. This drug blocks the free radicals and prevents the development of oxidation stress in animals.

The purpose of our research was to determine the effect of the drug «Metisevit» on the level of enzyme and nonenzyme system of antioxidant defense of the body in conditions of chronic bull cadmium toxicity.

\section{Material and methods}

Research were carried on farm in village Ivanivtsi, Zhydachiv district, Lviv region with 10 bulls six months 
of age, black and white breed that were formed into 2 groups ( 5 animals in each):

Group 1 - control (C), calves were fed with food cadmium chloride at a dose of $0.04 \mathrm{mg} / \mathrm{kg}$ body weight;

Group 2 - research (R), calves fed with food cadmium chloride at a dose of $0.04 \mathrm{mg} / \mathrm{kg}$ body weight along with «Metisevit» at a dose of $0.36 \mathrm{~g} / \mathrm{kg}$ feed.

When conducting research we followed the rules required when performing experiments on selection zootechnical and animal analogues in groups, technology procurement, use and accounting of consumed feed. The diet of the animals was balanced in nutrients and minerals that ensure their basic need for batteries.

Antioxidant drug «Metisevit» was developed at the Department of Pharmacology and Toxicology Lviv National Stepan Gzhytskyi University of Veterinary Medicine and Biotechnology which incorporates contains «Metifen», vitamin E and selenium. These components enhance each other's action and promote a better balance in the normalization of complex «System of antioxidant defense $\leftrightarrow$ Peroxidate oxidation of lipids».

The experiment lasted for 30 days. Blood for analysis were taken from the jugular vein in the 1-, 8-, 16-, 24-, and 30 th day of the experiment.

The activity of glutation peroxydase is determined by V.V. Lemeshko and others (Lemeshko et al., 1985); katalase activity (K.F. 1.11.1.6) - after the method of M.A. Korolyuk (Koroljuk et al., 1988); the activity of superoxide dismutase (SOD) (K.F. 1.15.1.1) - after the method (Chevari et al., 1985), reduced glutathione content was determined by the method (Butler et al., 1982), vitamins $\mathrm{A}$ and $\mathrm{E}$ were determined in blood plasma by high performance liquid chromatography (Vlizlo et al., 2012).

\section{Results and discussion}

Glutathione peroxidase (GP) - is an enzyme that protects the body from oxidative damage. It catalyzes the recovery and restoration of lipid peroxides hydrogen and peroxide to water. In these reactions the enzyme oxidezes glutathione. Furthermore, glutathione peroxidase takes place in redox regulation of various metabolic processes. Over $70 \%$ of GP is localized in the cytosol and $25-30 \%$ - in the mitochondrial matrix (Gutyj, 2013).

From the data presented in Table 1 it is shown that under conditions of chronic cadmium toxicity glutathione peroxidase activity in blood serum in animal control group on the first day of the experiment, has increased by $3 \%$ compared to the indices of blood taken prior after feeding with cadmium chloride. The lowest enzyme activity was on the twenty-fourth day of the experiment and was $27,7 \pm 1,24 \mathrm{nmol} \mathrm{NADPH} / \mathrm{min}$. to $1 \mathrm{mg}$ of protein. Subsequently, the research activity of the enzyme gradually increased, and on the thirtieth day was $31,1 \pm$ $1,20 \mathrm{nmol} \mathrm{NADPH} / \mathrm{min}$. to $1 \mathrm{mg}$ of protein.

After applying metisevit in bulls experimental group the activity of glutathione peroxidase increased, on the eighth day, according to $16 \%$. On the sixteenth day of the experiment, the activity of the enzyme in the experimental group of calves was $36,1 \pm 1,25 \mathrm{nmol} \mathrm{NADPH} / \mathrm{min}$. to 1 $\mathrm{mg}$ of protein. Later, glutathione peroxidase activity in blood serum of calves in experimental group continued to rise, and on the twenty-fourth day of the experiment it increased by $32 \%$.

Table 1

\section{The activity of glutathione peroxidase in the blood of bulls after feeding metisevit after chronic cadmium} toxicity; $(M \pm \mathbf{m}, \mathbf{n}=\mathbf{5})$

\begin{tabular}{|l|l|c|}
\hline \multirow{2}{*}{ Time of blood tests (day) } & \multicolumn{2}{|l|}{ Glutathione peroxidase (mmol NADPH / min per 1 mg of protein) } \\
\cline { 2 - 3 } & Groups of animals & control Pilot \\
\cline { 2 - 3 } & control Pilot & $36,2 \pm 1,20$ \\
\hline The original size & $36,6 \pm 1,23$ & $36,9 \pm 1,35$ \\
\hline The first day & $37,8 \pm 1,21$ & $35,9 \pm 1,18^{* *}$ \\
\hline The eighth day & $31,0 \pm 1,13$ & $36,1 \pm 1,20^{* *}$ \\
\hline The sixteenth day & $29,0 \pm 1,15$ & $36,5 \pm 1,30^{* *}$ \\
\hline The twenty-fourth day & $27,7 \pm 1,24$ & $36,6 \pm 1,25^{* *}$ \\
\hline The thirtieth day & $31,1 \pm 1,20$ & \\
\hline
\end{tabular}

Note: The degree of probability according the control group $-\mathrm{p}<0,05_{-}^{*}, \mathrm{p}>0.01$ - $^{* *}$

Thus, normalization of glutathione peroxidase in blood of calves after entering metisevit drew the first day, and the highest enzyme activity is set to the twenty-fourth and thirty-day of experiment.

Superoxide dysmutase - is one of the key enzymes of antiradical protection, which refers to the direct action of antioxidants. This enzyme rutes superoxideradical to peroxide, which is less toxic to the previous. Actually so SOD plays a crucial role in the antioxidant protection of almost all types of cells that are in contact with oxygen. SOD is primarily in the mitochondrial matrix, the cytosol and the cytoplasm (Gutyj, 2013).

For chronic cadmium toxicity in bulls on the first day of the experiment the activity of superoxide dismutase in the serum of animals in the control group increased by $10 \%$ compared to the initial values. Later in patients bulls enzyme activity began to decline according to the eighth day of the experiment it was $0,52 \pm 0,011 \mathrm{cu} / \mathrm{Mg}$ protein. The low activity of the enzyme was on the twenty-fourth day of the experiment, where a relatively initial value is decreased by $35 \%$ (Table 2 ).

In the bull, which together with the investigational toxin were fed drug «Metisevit», superoxide dismutase activity increased throughout the experiment on the values of the control group animals. On the eighth and sixteenth day of the experiment enzyme activity in the experimental group of animals was higher by 17 and $41 \%$ relative values of the control group animals. 
Table 2

Activity of superoxide dismutase in bulls' blood after feeding them with drug «Metisevit» for chronic cadmium toxicity; $(M \pm m, n=5)$

\begin{tabular}{|l|c|c|}
\hline \multirow{2}{*}{ Time of blood tests (day) } & \multicolumn{2}{|c|}{ Superoxide dismutase (u / mg protein) } \\
\cline { 2 - 3 } & \multicolumn{2}{|c|}{ Groups of animals } \\
\cline { 2 - 3 } & $0,62 \pm 0,012$ & $0,63 \pm 0,011$ \\
\hline The original size & $0,68 \pm 0,014$ & $0,67 \pm 0,012$ \\
\hline The first day & $0,52 \pm 0,011$ & $0,61 \pm 0,012^{*}$ \\
\hline The eighth day & $0,44 \pm 0,011$ & $0,62 \pm 0,010^{* *}$ \\
\hline The sixteenth day & $0,40 \pm 0,010$ & $0,63 \pm 0,011^{* *}$ \\
\hline The twenty-fourth day & $0,46 \pm 0,012$ & $0,64 \pm 0,013^{* *}$ \\
\hline The thirtieth day & \multicolumn{2}{c|}{} \\
\hline
\end{tabular}

The action of SOD is associated with the action of catalase, if one enzyme increases, the other not, so it contribute to the formation of large amounts of free radicals and increased lipid peroxidation.

Catalase recovers hydrogen peroxide to water. To the active center of the enzyme is trivalent iron protoporphyrin, which interacts with hydrogen peroxide by catalase, or peroxidase mechanism, depending on the concentration of the substrate. The enzyme is found in all tissues at a concentration of $10^{-6} \mathrm{M}$. Generally, the action of catalase is reduced to decrease the concentration of cytotoxic hydroxyl radicals. The highest catalase activity was found in the red blood cells, liver, kidneys. For high intensity formation of hydrogen peroxide in the body, he cleared catalase, and the low - glutatin antioxidant system (Gutyj, 2013).

So, catalase as the mechanism of action of antioxidant system defense refers to direct action. The activity of catalase in bull's blood serum in conditions of chronic cadmium toxicity and exposure to the drug "Metisevit" is shown in Table 3.

Table 3

The activity of catalase in blood after feeding bulls with drug «Metisevit» for chronic cadmium toxicity;

$(\mathbf{M} \pm \mathbf{m}, \mathbf{n}=\mathbf{5})$

\begin{tabular}{|l|c|c|}
\hline \multirow{2}{*}{ Time of blood tests (day) } & \multicolumn{2}{|c|}{ Catalase (units) } \\
\cline { 2 - 3 } & \multicolumn{2}{|c|}{ Groups of animals } \\
\cline { 2 - 3 } & \multicolumn{2}{|c}{ research group } \\
\hline The original size & $6,55 \pm 0,12$ & $6,54 \pm 0,16$ \\
\hline The first day & $6,46 \pm 0,13$ & $6,51 \pm 0,15$ \\
\hline The eighth day & $6,22 \pm 0,12$ & $6,52 \pm 0,16^{*}$ \\
\hline The sixteenth day & $5,75 \pm 0,14$ & $6,50 \pm 0,15^{* *}$ \\
\hline The twenty-fourth day & $5,65 \pm 0,11$ & $6,51 \pm 0,14^{* *}$ \\
\hline The thirtieth day & $5,93 \pm 0,12$ & $6,57 \pm 0,12^{*}$ \\
\hline
\end{tabular}

For chronic cadmium toxicity it was founded reduced activity of catalase in the blood of animals in the control group. The activity of this enzyme was decreased on the eighth day of the experiment to $5 \%$, on the sixteenth day $13 \%$ compared to the initial values.

On the twenty-fourth day of the experiment catalase activity in blood of animals which were fed with food cadmium chloride was low and accordingly was 5,65 \pm 0,11 units. On the thirtieth day of experiment, the enzyme activity increased slightly, but remained at a low level.

The use of «Metisevit» contributed to the increase catalase activity in blood of experimental animals. On the eighth day of the experiment enzyme activity increased by $5 \%$ for the values of the control group animals. On the sixteenth day of the experiment catalase activity in experimental group amounted to $6,50 \pm 0,15$ units. On the twenty-fourth day of the experiment indicated in these animals likely increased activity of the enzyme on the values of the control group animals at $15 \%$ respectively. On the thirtieth day of the experiment catalase activity in the first experimental group ranged within physiological values.
Thus, the drug «Metisevit» contributed to increasing activity of catalase, superoxide dismutase and that in animals play an important role in lipid peroxidation.

Glutathione is a major component of glutation antioxidant defense system. It consists of three amino acids: glutamic, cysteine and glycine. Glutathione does not only protect cells from toxic compounds and free radicals, but also defines the status of intracellular redox environment. In addition, it increases the resistance of cells to the negative effects of stress factors and is involved in the removal of xenobiotics. Actually so, glutathione is a key element in antioxidant system because it is able to restore other antioxidants (Gutyj, 2013).

Table 4 shows the changes in the level of reduced glutathione in the blood of bulls in cadmium stress. As can be seen from the table data glutathione level at the beginning of the experiment was within the physiological norm values. After feeding with cadmium chloride content of reduced glutathione began to decline. The lowest indicator was on the twenty- fourth day of the experiment, which according to the original values it decreased by $8 \%$. 
The level of reduced glutathione in the blood of bulls after feeding «Metisevit» after chronic cadmium toxicity, $\mathrm{mg} \%(\mathrm{M} \pm \mathbf{m}, \mathbf{n}=\mathbf{5})$

\begin{tabular}{|l|c|c|}
\hline \multirow{2}{*}{ Time of blood tests (day) } & Control group & Groups of animals \\
\cline { 2 - 3 } & $31,95 \pm 0,58$ & $33,14 \pm 0,55$ \\
\hline The original size & $34,21 \pm 0,62$ & $33,38 \pm 0,75$ \\
\hline The first day & $30,99 \pm 0,60$ & $33,55 \pm 0,76^{*}$ \\
\hline The eighth day & $29,95 \pm 0,65$ & $33,61 \pm 0,55^{* *}$ \\
\hline ThesSixteenth day & $29,49 \pm 0,55$ & $33,33 \pm 0,65^{* *}$ \\
\hline The twenty-fourth day & $30,25 \pm 0,65$ & $33,30 \pm 0,50^{*}$ \\
\hline The thirtieth day & & \\
\hline
\end{tabular}

The use of animal drug «Metisevit» contributed to raising the level of reduced glutathione in the blood of experimental animals on the eighth day of the experiment by $8 \%$, on the sixteenth day $-12 \%$. The most probable changes in the level of reduced glutathione in the experimental group of animals was founded on the twenty-fourth day of the experiment, in which the figure was $33,33 \pm 0,65 \mathrm{mg} \%$, and it was $13 \%$ greater than the value of the control group animals.

Equally important in antioxidant system include vitamin $\mathrm{E}$, which protects cell membranes from attack of free radicals and reactive oxygen species. Its content in the blood of animals by chronic cadmium toxicity is shown in Table 5. Feeding toxicant above helped to reduce the content of vitamin $\mathrm{E}$ in the blood of animals throughout the experiment. So, on the eighth day of experiment vitamin content was $3,3 \pm 0,11 \mathrm{mmol} / \mathrm{l}$, which is lower to $20 \%$ compared to the initial values. On the sixteenth day of vitamin $\mathrm{E}$ studies continued to decline and relative quantities of blood taken at the beginning of the experiment, that is for feeding bulls with cadmium chloride, decreased to $24 \%$, the twenty-fourth day of the experiment vitamin E decreased to $29 \%$.

Vitamin $E$ in the blood of bulls after feeding drug «Metisevit» by chronic cadmium toxicity, $\mathbf{m m o l} / \mathbf{l}(\mathbf{M} \pm \mathbf{m}, \mathbf{n}=\mathbf{5})$

\begin{tabular}{|l|c|c|}
\hline \multirow{2}{*}{ Time of blood tests (day) } & \multicolumn{2}{|c|}{ Groups of animals } \\
\cline { 2 - 3 } & control group & research group \\
\hline The original size & $4,1 \pm 0,11$ & $4,1 \pm 0,12$ \\
\hline The first day & $3,8 \pm 0,14$ & $4,7 \pm 0,10^{* *}$ \\
\hline The eighth day & $3,3 \pm 0,11$ & $4,8 \pm 0,15^{* *}$ \\
\hline The sixteenth day & $3,1 \pm 0,11$ & $4,9 \pm 0,12^{* *}$ \\
\hline The twenty-fourth day & $2,9 \pm 0,12$ & $4,8 \pm 0,13^{* *}$ \\
\hline The thirtieth day & $3,1 \pm 0,13$ & $4,5 \pm 0,12^{* *}$ \\
\hline
\end{tabular}

The applying of the drug «Metisevit» made the rising of vitamins, that were investigated in the blood of experimental animals feeding with toxicants. On the eighth day of the experiment it was founded increased content of vitamin E relative values of the control group of animals in research of blood by $45 \%$ respectively. Most likely increase vitamin was founded on the twenty-fourth day of the experiment.

We demonstrated that after the development of chronic cadmium toxicity in young cattle, vitamin A in their blood decreases. As can be seen from the data in Table 6, vitamin A after feeding with cadmium chloride began to fall on the first day to $4 \%$, on the eighth day $12 \%$, on the sixteenth day $-16 \%$, on the twenty-fourth day of the experiment $-27 \%$ relative initial values.

The use of experimental animals the drug of «Metisevit» boosted vitamin A in the blood of bulls under conditions of cadmium loading. Since the first day of the experiment we founded a gradual increase in the content of vitamin A in the blood of experimental animals Ratios control group of animals. On the sixteenth and twentyfourth day of the experiment vitamin A increased by 28 and $40 \%$ compared to the control group of animals.

The content of vitamin $A$ in the blood of bulls after feeding with drug «Metisevitu»

Table 6 by chronic cadmium toxicity, $\mathbf{m m o l} / \mathbf{l}(M \pm m, n=5)$

\begin{tabular}{|l|c|c|}
\hline \multirow{2}{*}{ Time of blood tests (day) } & \multicolumn{2}{|c|}{ Groups of animals } \\
\cline { 2 - 3 } & control group & research group \\
\hline Start value & $0,81 \pm 0,030$ & $0,82 \pm 0,031$ \\
\hline The first day & $0,78 \pm 0,018$ & $0,82 \pm 0,035^{*}$ \\
\hline The eighth day & $0,71 \pm 0,018$ & $0,84 \pm 0,035^{* *}$ \\
\hline The sixteenth day & $0,67 \pm 0,014$ & $0,86 \pm 0,029^{* *}$ \\
\hline The twenty-fourth day & $0,59 \pm 0,014$ & $0,85 \pm 0,030^{* *}$ \\
\hline The tirtieth day & $0,65 \pm 0,018$ & $0,84 \pm 0,025^{* *}$ \\
\hline
\end{tabular}


Thus, the applying of drug «Metisevit» for bulls who were under cadmium stress were contributed to the increase of antioxidants in nonenzyme system of antioxidation defense, such as vitamin A and vitamin E.

Overall, we received the research results indicating that feeding of bulls with drug «Metisevit» positively influences the antioxidant defense system in their body.

\section{Conclusions}

1. When feeding bulls with cadmium chloride at a dose of $0.04 \mathrm{mg} / \mathrm{kg}$ body weight and level indicators of nonenzyme and enzyme systems of antioxidant defense in the blood of experimental bulls decreased throughout the experiment. The lowest level of indexes in antioxidant system installed on the twenty fourth day of the experiment, which deals with enhanced activation of lipid peroxidation and the imbalance between the activity of antioxidant system and lipid peroxidation intensity.

2. The drug «Metisevit» in cadmium stress activates the enzyme and nonenzyme system of antioxidant defense system in bull's body, as it is indicated by increased activity of glutathione peroxidase, catalase, superoxide dismutase and glutathione increase of vitamins $\mathrm{A}$ and $\mathrm{E}$ in the blood of animals. Addition of «Metisevit» in feeding prevents the oxidation stress, that cause peroxide damages in cell membranes and the intracellular biopolymers.

Prospects for further researches. The results of research will be applied in subsequently studies of antioxidant defense and processes of lipid peroxidation in the blood of the bull to develop antidote drug for the treatment of animals in cadmium toxicosis.

\section{References}

Honskyy, Ya.I., Yastremskaya, S.O., Boychuk, B.R. (2001). Vikovi osoblyvostsi porushennya peroksydnoho okyslennya lipidiv i aktyvnosti enerhozabezpechuvalnyh fermentiv pry kadmiyeviy intoksykatsiyi [Age features breach of lipid peroxidation and activity of enzymes in utility cadmium intoxication] Medichna chimiya - Medical Chemistry. 3(1), 16-19 (in Ukrainian).

Gutyj, B.V. (2012). Vplyv hlorydu kadmiju na intensyvnist' procesiv perekysnogo okysnennja lipidivtastan systemy antyoksydantnogozahystu organizmu shhuriv. Visnyk Sums'kogo nacional'nogo agrarnogo universytetu. Serija : Veterynarna medycyna. 7, 31-34 (in Ukrainian).

Gutyj, B.V. (2013). Riven' pokaznykiv nefermentnoi' systemy antyoksydantnogo zahystu organizmu bychkiv za umov kadmijevogo navantazhennja. Naukovyj visnyk L'vivs'kogo nacional'nogo universytetu veterynarnoi' medycyny ta biotehnologij im. G'zhyc'kogo. 15, 1(4), 40-45 (in Ukrainian).

Gutyj, B.V. (2013). Vmist vitaminiv A i E u krovi bychkiv za umov kadmijevoi' intoksykacii'. Visnyk Sums'kogo nacional'nogo agrarnogo universytetu. Serija : Veterynarna medycyna. 2, 31-33 (in Ukrainian).

Gutyj, B.V. (2013). Vplyv E-selenu na aktyvnist' glutationovoi' systemy antyoksydantnogo zahystu organizmu bugajciv pry kadmijevomu navantazhenni. Visnyk Sums'kogo nacional'nogo agrarnogo universytetu. Serija : Veterynarna medycyna. 9, 70-73 (in Ukrainian).

Gutyj, B.V. (2013). Vplyv E-selenu na vmist vitaminiv A i E u krovi bychkiv za umov kadmijevoi' intoksykacii'. Naukovyj visnyk L'vivs'kogo nacional'nogo universytetu veterynarnoi' medycyny ta biotehnologij im. G'zhyc'kogo. 15, 3(3), 311-314 (in Ukrainian).

Gutyj, B.V. (2013). Vplyv meveselu na vmist vitaminiv A i E u krovi bychkiv za umov kadmijevoi' intoksykacii'. Naukovyj visnyk L'vivs'kogo nacional'nogo universytetu veterynarnoi' medycyny ta biotehnologij im. G'zhyc'kogo. 15, 3(1), 78-82 (in Ukrainian).

Gutyj, B.V. (2013). Vplyv meveselu ta E-selenu na riven' pokaznykiv ne fermentnoi' systemy antyoksydantnogo zahystu organizmu bugajciv pry kadmijevomu navantazhenni. Veterynarna medycyna. 97, 419-421 (in Ukrainian).

Gutyj, B.V. (2013). Vplyv preparatu «Mevesel» na aktyvnist' enzymnoi' ta neenzymnoi lanok antyoksydantnoi' systemy organizmu bugajciv za umov hronichnogo kadmijevogo toksykozu. Biologija tvaryn. 15(4), 39-46 (in Ukrainian).

Gutyj, B.V. (2015). Aktyvnist' systemy antyoksydantnogo zahystu organizmu bychkiv za gostrogo kadmijevogo toksykozu. Naukovyj visnyk L'vivs'kogo nacional'nogo universytetu veterynarnoi' medycyny ta biotehnologij im. G'zhyc'kogo. 17, 1(1), 31-36 (in Ukrainian).

Gutyj, B.V., Murs'ka, S.D., Gufrij, D.F., Hariv, I.I., Levkivs'ka, N.D., Nazaruk, N.V., Gajdjuk, M.B., Pryjma, O.B., Bilyk, O.Ja., Guta, Z.A. (2016). Vplyv kadmijevogo navantazhennja na systemu antyoksydantnogo zahystu organizmu bugajciv. Visnyk Dnipropetrovs'kogo universytetu. Biologija, ekologija. 24(1), 96-102 (in Ukrainian).

Melnychuk, D.O., Melnikova, N.M., Derkach, E.A. (2004). Vikovi osoblyvosti kumulyatsiyi kadmiyu v orhanah toksykovanyh schuriv i zminyu pokaznykivi kislotno-luzhnohogo stanu krovi za riznyh umov antyoksydantnoho zahystu orhanizmu [Age characteristics of cadmium accumulation in organs toksykovanyh rats and changes in rates of acid-base balance of blood under different conditions antioxidant body] Ukr. biochim. jurnal - Ukr. Chem. Journal, 76(6), 95-99 (in Ukrainian).

Melnychuk, D.O., Trachtenberg, I.M., Melnikova, N.M., Kalinin, I.V., Shepeleva, I.A., Derkach, E.A. (2002). Toksykolohichnyy vplyv soley svyntsyu ta kadmiyu na bioihimichni pokaznyky i laboratornyh tvaryn [Toxicological effects of lead and cadmium salts on bioihimichni parameters in laboratory animals] Naukovyy visnyk NAU. Scientific Bulletin of the NAU. 55, 117-119 (in Ukrainian).

Butler, E., Dubra, A., Kelly, B. (1982). Metodika opredeleniya urovnya vostanovlenogo glutationa $\mathrm{V}$ eritrotsitah krovi [Tekst] metodicheskie rekomendatsii po differentsialnoy diagnostike razlichnyh form ishemicheskoy bolezn serdtsa $\mathrm{s}$ ispolzovaniem opredeleniya komponentov glutationovoy, protivoperekisnoy katalicheskoy sistemy $\mathrm{v}$ eritrotsitah 
krov [Methods of determining the level of glutathione in repairing the red blood cells [Text]: guidelines for the differential diagnosis of various forms of ischemic heart disease using the definition of the components of glutathione, protivoperekisnoy catalyzed system eritrotsitah blood]. Odessa, 16-20 (in Russian).

Koroljuk M.A., Ivanov L.I., Mayorov I.G., Tokarev V.E. (1988). Method opredeleniya aktivnosti katalazy. Lab. delo. 1, 16-18 (in Russian).

Lemeshko, V., Nikitenko, Y., Lankin, V. (1985). Fermenty utilizatsii godroperoksidov $\mathrm{i}_{2} \mathrm{v}$ miokarde krys raznogo vozrasta. Byul. eksp. biol. i mead. 5,
563-565 (in Russian).

Chevari, S., Csaba, I., Szekely, J. (1985). Rol superoxide v okislitelnyh protsessah kletki i metod opredeleniya ee $\mathrm{v}$ biologicheskih materialah. Lab. delo. 11, 678681 (in Russian).

Vlizlo, V.V., Fedoruk, R.S., Ratych, I.B. (2012). Laboratorni metody doslidzhen' u biologii', tvarynnyctvi ta veterynarnij medycyni: dovidnyk. L'viv: Spolom (in Ukrainian).

Стаття надійшла до редакиії 1.09.2016 